\title{
A SPANISH “YES, WE CAN!" AGAINST THE TWO-PARTY SYSTEM:THE DEVELOPMENT OF POLITICAL PARTY PODEMOS
}

\author{
Guillermo López García \\ Department of Theory of Language \& Communication Sciences \\ Faculty of Philology, Translation \& Communication \\ University of Valencia \\ E-mail: guilopez@gmail.com
}

DOI: 10.20901/an.13.06

Prethodno priopćenje Primljeno: listopad 2016.

\begin{abstract}
Summary This article develops an analysis of the internal functioning of the Spanish party Podemos and its structural make-up. The used methodology consists of: 1) a descriptive analysis of the development of Podemos, based on the available information in the media; 2 ) an analysis centered on the presence of Podemos in social networks and the mainstream media, in addition to electoral results and polls. The analysis attempts to determine the following: the party's decision-making process, along with the type of relationships established between leaders and supporters; to what extent the Internet is used as a primary tool for organization, mobilization and political propaganda; and the extent of the clash or harmony within the interparty's dynamics: on one hand, the bottom-up structure of the citizen assemblies and, on the other, the top-down structure inferred from Pablo Iglesias's hyper-leadership and the media presence of the party's principal leaders. ${ }^{1}$
\end{abstract}

Keywords Podemos, European Elections, New Media, Spanish Politics, Political Populism

\section{Introduction}

Spain is one of the countries hardest hit by the global economic crisis that

1 This study has been realized under the research project Communication flows in processes of political mobilization: the media, blogs and opinion leaders (MEDIAFLOWS) (20142016), funded by the Spanish Ministry of Economy and Competitiveness (Ref. CSO201343960-R). began in 2007. As in other southern European countries, the introduction of the Euro led to considerable debts both in the public and private sectors. In Spain, this debt revolved around a "building craze" that spurred the construction of many housing and public works projects. However, the real estate bubble burst as a result of the crisis and caused severe social and economic consequences. 
The economic situation has been accompanied by a rapid deterioration of the political climate in Spain, stemming from a decline in the credibility of politicians and representatives from major national institutions. As a result, voters have punished the country's two main political parties: the socialist PSOE party that governed from 2004-2011, and the conservative Partido Popular (PP). However, public polls that, as of very recently (2012) showed a sharp decline in credibility amongst political parties and traditional political figures, for years did not show electoral consequences stemming from negative public opinion. This is partially due to the inability of the major alternative parties (which are more or less also considered traditional parties) to attract votes. This led to a significant portion of the electorate abstaining from voting altogether.

Opposition to traditional politics clearly manifested itself in the emergence of the indignados movement on May $15^{\text {th }}$ 2011 (15M movement). Protestors aligned with this movement occupied public squares in the largest Spanish cities for several weeks, and undoubtedly brought about changes in the political agenda (Casero-Ripollés and Feenstra, 2012). Traditional political parties even recommended that $15 \mathrm{M}$ activists form an official political party if they really wanted to effect change, but $15 \mathrm{M}$ never became a full-fledged political movement. Many people wondered how it was possible that no new electoral option appeared on their ballots, in the same vein as Syriza in Greece or Beppe Grillo's MoVimento 5 Stelle (M5S) in Italy, to channel the people's dissatisfaction and benefit from the obvious crisis affecting the political system.

Curiously, the party that would emerge as this alternative, known as Po- demos, is, at first glance, a type of hybrid that takes from both sides of the spectrum. Podemos feeds off of populist rhetoric and practices, as does M5S, but at the same time clearly traces its roots to leftist parties in the political sphere, as does Syriza. The first time that Podemos candidates appeared in an election, during the 2014 European Elections, they achieved good results: around $8 \%$ of the total votes cast and 5 seats in the European Parliament. These are excellent numbers for a new political party (Podemos was founded in January 2014, the same year as the aforementioned elections), that barely had the means to run an electoral campaign and mainly relied on the media presence of its leader, Pablo Iglesias.

The emergence of Podemos was a real shock to Spanish politics, despite the perplexing fact that, for years, Spanish society was apparently unable to create successful alternatives capable of entering the political sphere. However, this was not all that changed in the 2014 European Elections. In addition, the PP and PSOE obtained a combined $49 \%$ of the vote total; the first time in the history of the two-party system, which has traditionally been very strong in Spain, that they failed to earn at least $50 \%$ of the ballots cast (see graph 1).

The day after the elections took place, Alfredo Pérez Rubalcaba, the head of PSOE, resigned as a consequence of his party's poor returns, the lowest in its history (23\% of the votes). The following week, King Juan Carlos I, whose popularity had significantly withered, announced his decision to abdicate the throne and proclaim his son Felipe the new king. Over the next few months, polls showed increasing support for Podemos, so large that they showed a three-way tie with PP and PSOE, the powerhouses in Spain's two-party system. 
Graph 1. Percentage of the vote earned by the two major Spanish political parties in European Parliament Elections, 1987-2014.

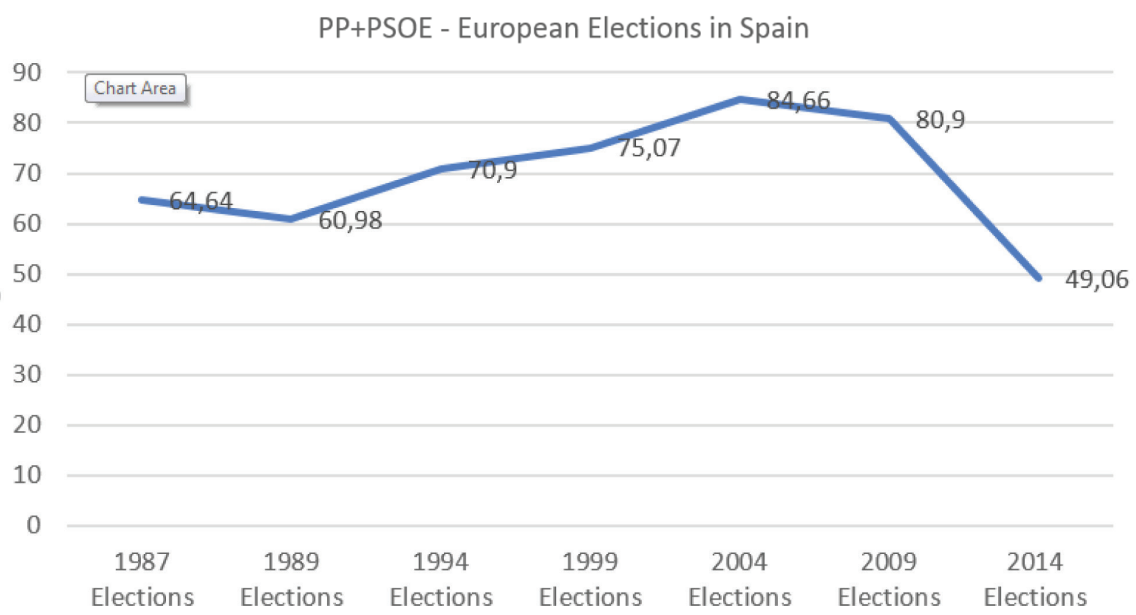

Source: Boix and López (2014)

This is the context that we wish to analyse in the upcoming sections of this article. We hope to study the evolution of Podemos, from its beginnings to the current day, its strategies and ideological roots, the organization of its internal structures, its relationship with its supporters, and finally, what the numbers and figures tell us.

\section{Purpose of the study and methodology}

We believe that interest in Podemos is undeniable. Podemos is the first political party since 1982 that has threatened the dominance of the Spanish two-party system. We are concerned with determining the main elements to be included in our analysis, whose structure is based primarily on two goals. First is the study of the organizational structure of Podemos, its ideological framework, and its political and media strategies. That is to say, everything that categorizes Podemos as a political party. Second is to analyse the path that Podemos has taken during its first year in existence, as well as its impact on various aspects of public opinion: media outlets, public opinion polls, social protests, and of course elections.

The research methodology applied here is in line with these two goals and combines two main parameters: a quantitative data analysis (election results, opinion polls, rallies, social media presence, information released through media outlets, etc.); and a qualitative analysis of speeches and strategies utilized by Podemos during interviews, conferences and discussion groups organized by research group Mediaflows ${ }^{2}$ with various representatives from Podemos. The combination of this particular material with academic articles already published will allow us to establish more clearly our research goals outlined previously.

\section{Podemos: origins, strategies and operation}

Podemos was "born" on January $17^{\text {th }}, 2014$ when various leftist political

2 For details see www.mediaflows.es 
activists, primarily based in Madrid (specifically from the political science department of the Complutense University of Madrid, where Podemos's leadership originated) published a manifesto. Pablo Iglesias, the undisputed leader of the party, Íñigo Errejón, second-in-command and chief political strategist, and Juan Carlos Monedero, Podemos's third highest member, ${ }^{3}$ all had established their academic careers in this department. Other important leaders in the young party include Carolina Bescansa, head of electoral analysis and polls, and Luis Alegre. Almost all of these figures have a long history of political activism and are often linked to progressive populist governments in Latin America, particularly that of Hugo Chávez in Venezuela (Rivero, 2015: 82-88).

The founding of Podemos also has much to do with two other phenomena that took place. Firstly, there was the inability of the leftist political bloc, Izquierda Unida (IU), to benefit from the waning credibility of the two-party system and their refusal to hold primary elections to choose candidates for the 2014 European elections. Podemos initially sought to force IU to call for open primaries and, if these primaries were not held, the prior would run independent campaigns. In addition, Podemos leaders were aware of the fact that the mediatisation of politics was essential in forging new political leadership. Media outlets, specifically television, with their unique ability to condense messages and present them effectively to large audiences, are considered to be the playing field utilized by the new breed of politics (Mazzoleni, 2014: 43).

3 Monedero eventually left politics just before the regional and local elections on May $24^{\text {th }}$, 2015.
The concept of political participation and activism through the media did not originate with Podemos, but its effectiveness was corroborated by the Podemos experience. In 2010, a television program called La Tuerka was created that consisted of political discussions moderated by Pablo Iglesias. The program aired weekly on various local television stations in Madrid, and also reached a wider audience through internet broadcast. Many future leaders of Podemos gained invaluable experience from their participation on La Tuerka, learning how to handle themselves in front of the cameras and especially how to debate on television against individuals who represented ideologies opposed to their own. This constituted an essential learning experience for Podemos leaders in terms of situating themselves in the conceptual framework of mediatized politics, in which television plays the most important role. As Iglesias himself stated:

Political discourse now more than ever is built around audiovisual products and devices. What we have here is a battle to define what reality is (...) People believe that the battle is waged between parties or political groups, but that's not true. The battle is fought in the media (Domínguez and Giménez, 2014: 15).

Starting in 2014, Pablo Iglesias became a regular guest on political debate programs on different national television channels. He began by appearing as the "exotic" counterpoint on more conservative programs with small, yet not insignificant audiences in discussions that were heavily biased to defending the conservative order. Later, towards the end of 2013, Iglesias made the jump to other political debate programs on major private television stations in Spain, primarily La Sexta and Cuatro. Both 
channels (especially La Sexta) have lately become outlets for analysis, information and opinions that are critical of Partido Popular and that espouse a progressive point of view. On these programs, Iglesias debated with leaders from the major political parties and also with (or rather, against) renowned journalists from conservative media.

This media presence is essential to understanding Podemos's success and goes hand in hand with its ideological base. There are two main intellectual foundations that underpin Podemos's methods, and especially those of its chief political strategist, Înigo Errejón. First, there is the notion of populism, which comes from the work of Argentine political scientist Ernesto Laclau (2005). Errejón, following the writing of Laclau, has called for a different type of populism that distances itself from classical revisionists, and that leans towards a more critical evaluation of its characteristics and effects (Taguieff, 2002). This breed of populism eschews ideological parameters that fall directly in line with the left-right political spectrum. Instead, it seeks opportune moments to occupy major spaces that have been ignored by existing powers, giving these spaces meaning and the ability to mobilize politically through discourse (Errejón, 2015: 133-134). This is a strategy that, as we have seen, had enormous potential in Spain, given the disconnection between the majority of citizens and the representatives of traditional parties, especially with regards to a few key pressing issues (such as unemployment, housing, and the decline in public services).

In addition, Podemos's strategies were heavily influenced by the works of Italian Marxist thinker Antonio Gramsci. Of particular weight was Gramsci's concept of "hegemony" and discursive strategies that could be employed by social actors to achieve it. The "discourse" would be the packaging for what has already taken place, like a set of recognized and unrecognized activities that make sense out of certain social facts. Political discourse in this context presents itself as a permanent translation of reality, redefining what makes sense.

In such a translation, simplification is inevitable. The discourse begins with complex situations and ideas that are necessarily transferred to the public sphere condensed and summarized (Domínguez and Giménez, 2014: 90). Reality is often reduced to stereotypes easily handled and assumed by the public. This is what occurs in the media and in the products of the culture industry, for example, but also in more immediate, smaller social circles such as group conversation, whether in person or online. It goes without saying that the same happens in institutional discourse, as well.

As previously mentioned, these foundations established a political strategy that blurred the classic dialectics revolving around right and left. The discourse traced by Podemos assumes an underlying political and social hegemony in opposition to an institutional system hijacked by the traditional parties in harmony with the interest of the elites or, in other words, the classic dialectics of populism (Kessel, 2014: 101), structured around distinctions between the "People" and the "Elites", "those on top and those at the bottom", etc., so common throughout Podemos's rhetoric.

These discursive strategies, simplified in order to captivate the larger public, were applied through Pablo Iglesias's many appearances in the media, the main source of Podemos's notoriety and channel of access to the public during 
the party's first few months as well as now. Nonetheless, Iglesias undoubtedly garnered the lion's share of his fame on television, where he could deliver his message to millions of people. TV is also his party's primary tool for spreading its ideas and arguments, condensed and simplified in a TV-friendly fashion, such as the aforementioned idea of the "elite" (an idea that is also commonplace in the rhetoric of Beppe Grillo and his M5S movement). This elite (la casta in Spanish) refers to Spain's political-economic establishment defended by the PP and the PSOE, which is in opposition to the "People" (represented by Podemos). Also present is the notion of "patriotism" as a value unbefitting of a corrupt political-economic class that commits tax evasion and allows fundamental public services such as healthcare and education, highly valued by the Spanish people, to deteriorate. These dialectics have been extremely important in Podemos's ability to communicate, from the get-go, with heterogeneous groups of people, whether in terms of economic class, politics or geography.

The 2014 European Elections campaign revolved around the figure of Iglesias, given that the vast majority of Spaniards were unaware of Podemos's existence, even at the moment of casting their votes. So it was that, according to Sarah Bienzobas in the Seminar organized by the Mediaflows Group in November 2014 (Periodismo.umh.es, 2014) the campaign made an important strategic decision: the Podemos ballot would feature an image of Iglesias himself as its logo, given that, although only 6 per cent of Spaniards knew of Podemos the day of that decision (March 2014, two months before the elections), more than half of the country knew who Iglesias was.
Naturally, as Podemos's initiative bore fruit, the party continued with the same strategy. Iglesias established an indisputable hyper-leadership of his party, despite some tensions. This was because, above all, Iglesias and the group of leaders around him, who also come from the Complutense University of Madrid, gradually sought to establish a highly hierarchized command structure, as opposed to the horizontal (and anarchic) character of the "Circles", the local or sectorial assemblies that had been organized throughout the country as the primary structure of the new party, even before the May 2014 elections.

The circles and the party itself established two complementary structures, which to some extent derive from the experience of many Podemos activists in the 15M movement (Micó and Casero-Ripollés, 2013: 6-9): the actual assemblies, carried out in Spanish cities and towns, on the one hand, and the constant debate, dissemination of advertisements and the amassing of resources that took place, from the onset, via Internet and novel initiatives such as crowd-funding, in order to finance the electoral campaign and the party's later acts, on the other (Fenoll and Sánchez, 2016). By the same token, most decisions were made via online voting of Podemos sympathizers, there was a specific Reddit page for discussion revolving around the party and, of course, the party was ubiquitous throughout social media, which we will discuss later on.

The tension between Iglesias's high profile, the core of leaders and the decentralized nature of the local assemblies resolved in the party's founding conference in Vistalegre, Madrid in October 2014. In it, Iglesias is elected as the party's Secretary General and Podemos establishes a leadership structure in which 
power is highly centralized in the hands of Iglesias and his followers, elected in the "Citizen State Council" (Podemos's main governing body).

From that moment on, it has been crystal clear that Podemos is, above all else, the party of Pablo Iglesias, and that the populist dialectics, the call upon the "People" to get involved in various public issues, is highly influenced by the manipulated figures of hyper-leadership who, at the moment of truth, will be the embodiment of that rhetoric, both in the media and in political action. In fact, Iglesias imposed an election model for the $20^{\text {th }}$ December elections that was totally closed and centralized and featured but one, non-negotiable list. In other words, in the struggle between the hyper-leadership media figures and the decentralization and horizontalness of the assemblies, the former has once again come out on top.

\section{Podemos in numbers}

As previously discussed, Podemos's media strategy is inseparable from its political strategy and, in fact, the success of the former has largely led to the success of the latter. The media presence has been achieved in all kinds of media, but from the onset two have stood out: the marked use of TV, on the one hand, and the use of the Internet and social media as a way to spread messages, forge consensus and mobilize the electorate, on the other (Casero-Ripollés et al, 2016).

Both strategies have developed at roughly the same time and feed into each other. For example, Iglesias and his followers first appeared on TV on the show La Tuerka in 2010. Shortly thereafter, in 2011, Iglesias began to use Twitter. His presence online and in social media have been an important factor explain- ing Iglesias's attractiveness for TV shows, as this presence allows the shows to reach a younger audience and re-disseminate interviews and conferences given by Iglesias (and later by other Podemos leaders, too) on the Internet, thereby increasing their impact. This strategy obviously interests Podemos, as well. Private TV channels and Podemos have established a virtuous cycle of large audiences and social impact through online networks - whether simultaneously or following the TV broadcast for the benefit of both parties.

Actually, the audience share explains a good deal of Podemos's TV popularity: the fact that Pablo Iglesias had been invited to participate in political talks long before Podemos came into being. Political debate programs, which began to proliferate on Spanish TV starting in 2013, rely on Podemos leaders (preferably Iglesias himself) to improve their ratings. For months, Podemos has been on the tip of everyone's tongue, including that of its political rivals.

Following the electoral surprise of May $25^{\text {th }} 2014$, the audience ratings demonstrate the party's popularity, as well as that of Iglesias. His appearance on a TV program can cause its ratings to skyrocket. For example, the Iglesias interview on Telecinco's news hour (the main privately-owned channel in Spain) in February 2015 garnered more than a $22 \%$ share. Not long before that interview, the same Telecinco program featured interviews with the Prime Minister Mariano Rajoy (19\% share) and the leader of the opposition, the socialist Pedro Sánchez (16\% share) (Elmundo. es, 2015). During Iglesias's first appearance on the "all news" TVE 24 Horas, the program earned a $3.1 \%$ share, three times higher than usual. Likewise, on $L a$ Sexta Noche, La Sexta's main political 
debate show, Iglesias has always earned the program considerably greater audiences. As Iglesias himself explained on the program Salvados, his TV success is no mystery: "private channels feature us because we're profitable and we give them audience, not because of freedom of expression" (Formulatv.com, 2014: 1).

The TV popularity of Podemos and Iglesias also has a multiplier effect on the Internet, particularly on social media. Their most controversial YouTube videos earn millions of views and become extremely viral. As aforementioned, debate on social networks regarding TV programs is also a source of visibility and "social contagion" for Podemos. Take, for example, public television's 24 Horas, during which the host insinuated that Pablo Iglesias supported the terrorist group ETA. The comment outraged the public on Twitter. More than 20,000 people published nearly 100,000 tweets about the interview. $40 \%$ of those tweets made use of the hashtag proposed by Podemos, \#Pabloen $24 \mathrm{H}$, instead of the show's official \#LNPabloIglesias, which was used in only 25\% (Globalinmedia. com, 2016). Social networks are another extremely important ingredient for the success of Podemos.

Their presence on Twitter and Facebook is much greater than that of any other political party, whether dealing with the parties' general accounts or those of the leaders themselves. The table 1 features the four national parties who had the best results in the recent legislative elections, in addition to their national leaders. As the table shows, Podemos and Pablo Iglesias's presence on Twitter is much greater than that of any other party or leader. We find similar numbers for Facebook (see table 2). The official Podemos account has the most followers and is the primary channel through which the party spreads its messages and entertains dialogue with users. Both Podemos and Iglesias are much more popular online than any of their rivals, despite the fact that the latter have been using social media for much longer and, in the case of Mariano Rajoy, have much greater visibility given the incomparable amount of attention garnered by any prime minister.

The question remains: to what does Podemos owe its dominance? On the one hand, as we shall discuss later, Podemos undoubtedly relies on a younger electorate than the PP or PSOE, a demographic perhaps more accustomed to using social networks. On the other, it is clear that the new parties, not just Podemos, strongly prefer social networks to spread stories of interest as well as to organize the party internally (Casero-Ripollés et al, 2016). Some organizations, such as the Italian MoVimento Cinco Stelle, are in fact built almost entirely online (Giansante, 2015: 43). Podemos is another example where the lack of resources and a physical locale, at least at the beginning of the party's life, has to be substituted by a constant online presence.

Lastly, it should be made clear that Podemos and Iglesias not only use the Internet, rather they also use it well. The Internet and social networks in particular are platforms for communication, debate, channelling political affinities, forging consensus and, in short, political mobilization. Here it is not simply a fruitless, for-show procedure, as it has been with the "old" parties (López et al, 2015). Quite the contrary, Podemos and Iglesias have sought to involve social media users and make them participants in a virtuous cycle: on the Internet, one's audience is responsible for spreading one's message. 
Table 1. Twitter followers of Spanish political parties and leaders, as of 12 August 2016

\begin{tabular}{|l|r|r|}
\hline \multicolumn{1}{|l}{ Account } & \multicolumn{1}{l}{ Tweets } & \multicolumn{1}{c}{ Followers } \\
\hline PP & 43,400 & 570,000 \\
\hline PSOE & 63,400 & 457,000 \\
\hline Ciudadanos & 70,300 & 347,000 \\
\hline Podemos & 68,900 & $1,130,000$ \\
\hline Mariano Rajoy (PP) & 17,800 & $1,250,000$ \\
\hline Pedro Sánchez (PSOE) & 19,500 & 381,000 \\
\hline Albert Rivera (Ciudadanos) & 42,400 & 654,000 \\
\hline Pablo Iglesias (Podemos) & 12,500 & $1,830,000$ \\
\hline
\end{tabular}

Source: author

Table 2. Facebook followers of Spanish political parties and leaders, as of 12 August 2016

\begin{tabular}{|l|r|}
\hline \multicolumn{1}{l}{ Account } & \multicolumn{1}{c|}{ Followers } \\
\hline PP & 162,216 \\
\hline PSOE & 134,781 \\
\hline Ciudadanos & 274,096 \\
\hline Podemos & $1,090,524$ \\
\hline Mariano Rajoy (PP) & 220,758 \\
\hline Pedro Sánchez (PSOE) & 143,298 \\
\hline Albert Rivera (Ciudadanos) & 292,778 \\
\hline Pablo Iglesias (Podemos) & 648,750 \\
\hline
\end{tabular}

Source: author

Podemos definitively corroborates Chadwick's theory (2013) regarding the characteristics of a hybrid media system in which both the new and old media would have a role. According to Chadwick, those political activists capable of exploiting the system's potential and the intersections of old and new media would especially benefit from the hybrid system.

The public's active role is further exemplified by online voting mechanisms, used often by Podemos, which are, furthermore, open to anyone who wants to enrol in the voting process or register as

a candidate. Voters come out in droves: the aforementioned founding assembly in Vistalegre saw more than 95,000 people vote for Iglesias's list of candidates in an event that helped him consolidate his power at the head of the party. Eightyfive thousand people voted in January 2015 in order to elect Podemos's local leaders throughout Spain, whereas more than 100,000 participated in a demonstration convoked by Podemos in Madrid on January $31^{\text {st }}, 2015$, during which the party presented itself as the main alternative to the PP during the soon to begin electoral odyssey. 
The numbers appear to corroborate the democratic nature of Podemos and the party's respect for the citizenry's opinion. Nonetheless, we also see - as Bimber (1998) pointed out ahead of his time - a new example of the practical limitations of direct democracy models and of the fascination with "accelerated pluralism": emphasizing a mass democratic model, which allows for more and more hierarchized and one-directional actions by the party, and by Iglesias himself, through voting which is largely directed by Iglesias's charisma and his visibility, unmatched by that of any alternative. Furthermore, alternatives are systematically isolated from access to the list of candidates and the decisionmaking process. The party's origins may be democratic, but the composition of power excludes any chance of integrating dissenting voices.

In this general review of the data on Podemos and of what we can glean regarding the party's trajectory and characteristics, the most crucial thing is left to be scrutinized: the votes. On the one hand, there are the actual votes that Podemos has earned in the five electoral contests to date, while on the other, there are the projections of subsequent opinion polls.

Podemos won $8 \%$ of the vote in last $25^{\text {th }}$ May's European Elections, enough to make it the fourth-most voted for party. No poll had predicted such strong results, and most said the party would fail to win any seats (it won five). This should not be surprising: public opinion surveys tend to be conservative and undervalue the responses of those polled, who often state their intention of voting for a new party without this intention translating to actual votes. This tendency has held true with Podemos: the party typically has higher voter intention fig- ures than its main rivals (the PP and the PSOE), whose voters tend to hide their intentions to a much greater degree.

The trends in voting intention for Podemos speak for themselves. The following graph is based on the average of the main voting intention polls in Spain between the 2011 and 2015 legislative elections. The graph shows stagnant voting intention for the two major parties before the emergence of Podemos. Support for the two major parties has clearly eroded, for the PP in particular, given that this party has been in power and the PSOE had suffered a major setback in the previous legislature, as a direct cause of its Government's performance. The alternatives to the two-party system, IU and UPyD (the maroon and magenta lines, respectively), also rise, but to a much lesser extent, and cannot capture the voters who abandoned the PP and PSOE and mostly abstain from voting.

The emergence of Podemos, as seen in the graph, rapidly changes that situation. The first polls following the May 2014 elections give Podemos a voting intention of $15 \%$, almost twice that obtained on $25^{\text {th }}$ May. This is largely due to the bandwagon effect of the party's electoral results and the fact that many potential Podemos voters learned of the party's existence and above all of the possibility that a vote for the party constitutes an effective "protest vote" (Fernández-Albertos, 2015: 38).

After the summer and until the end of 2014, Podemos's voting intention continues to rise, even surpassing the PSOE and, in many polls, the PP, too. Thus, according to many polls, it becomes a party capable of winning legislative elections. Nonetheless, beginning in late January or early February of 2015, this tendency begins to subside, and although Podemos never falls below the 


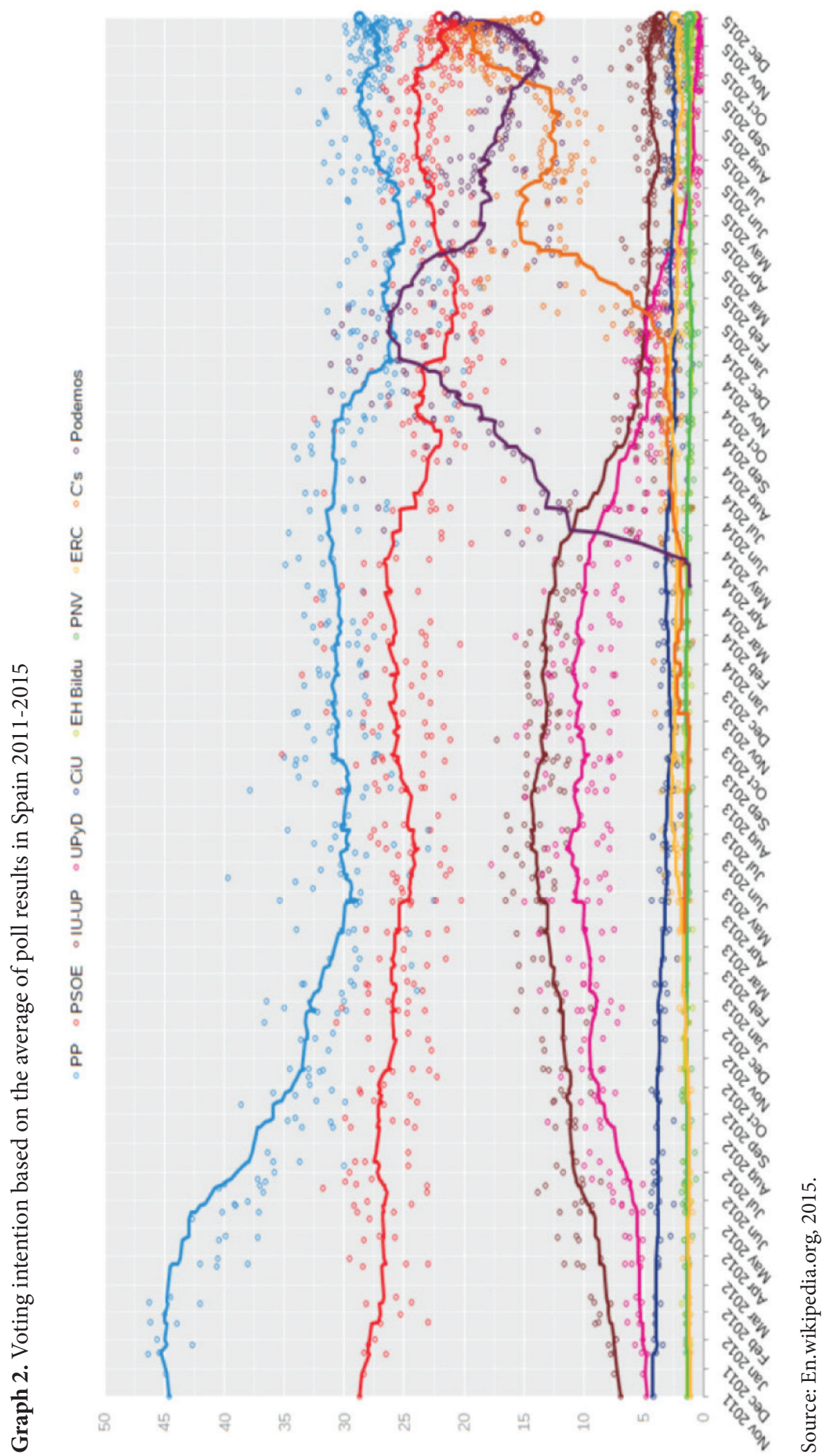


voting intention of 15\% (an important level in Spain, given that this is the floor above which electoral penalization caused by distribution of seats in what are often sparsely populated regions beings to significantly taper off), it never reaches PP or PSOE levels of voting intention. We have determined three potential explanations for this change.

Firstly, the emergence of Ciudadanos (eng. Citizens) had effect. As Podemos rose, many conservative voices clamoured for the formation of a "right-wing Podemos", which would carry out more or less the same electoral mobilization function among abstaining PP voters (Podemos depends much more upon ex socialist voters and ex IU voters). That "right-wing Podemos" turns out to be Ciudadanos, a party born in Catalonia and vehemently opposed to Catalonian nationalism. Ciudadanos leverages the European Elections as a way to introduce itself in Spain (it obtained two European seats). The party benefits from the near disappearance, in just a few months, of the centrist UPyD, in addition to the media visibility and charisma of its leader, Albert Rivera, who in many ways can be considered the "right-wing Pablo Iglesias". As logic would have it, Ciudadanos' strong 'mise-en-scène' was a threat to the other parties, especially the PP and Podemos.

Secondly, variations in strategy were important. As previously mentioned, Podemos has a before and after moment following its founding assembly in Vistalegre, in October. From that moment on, Podemos becomes a much more explicitly hierarchized project, controlled by its leaders and by Pablo Iglesias. Still more, it tries to change its positions, coming much closer to the political centre, and attempts to avoid "scaring" the electorate. This change in strategy can be seen in the media, where Podemos's appearances on TV, and particularly those of Iglesias, are much more spaced out beginning in November 2014 (following an interview with La Sexta journalist Ana Pastor, who puts Iglesias in a tough spot on several occasions). It is hard to know if Podemos's fall is a direct consequence of these changes, but clearly, the party is unable to temper the public's perception of Podemos as a farleft party. Also palpable are the media's attacks on Podemos, especially regarding its ties with Venezuela and the ideological principles and experience of the party bosses.

Thirdly, in March and May of 2015 Podemos faces two back-to-back electoral contests, its first since the European Elections. The results, albeit good, and undoubtedly praiseworthy for such a young party, fail to meet expectations. Podemos obtained $15 \%$ of votes in Andalusian regional elections in March, along with similar results in the 13 regions that held elections in May. In no region does it manage to surpass the $\mathrm{PP}$ or the PSOE or form a government. It does achieve excellent results in some of the country's major cities, and Podemos-backed candidates win the mayorship in Madrid, Barcelona (the country's second city) and in Zaragoza (the fifth-largest city), among others. Nonetheless, we should point out that these candidates did not pertain exclusively to Podemos, rather they were popular unity candidacies in which Podemos and other parties and organizations, generally led by nonpartisan public figures, participated. Thus, in these cases, victory, though undeniable, was not the exclusive property of Podemos. In addition, the bad results in Catalonian regional elections, held in September 2015, increased the perspective that Podemos' descent was beginning. 
Table 3. Percentage of vote obtained by PP, PSOE and Podemos in the 2014-2016 Spanish electoral season

\begin{tabular}{|l|r|r|r|r|}
\hline \multicolumn{1}{l}{ Elections } & \multicolumn{1}{c}{ PP } & \multicolumn{1}{c}{ PSOE } & \multicolumn{1}{r}{ Podemos } & Ciudadanos \\
\hline European elections (May 2014) & $26.06 \%$ & $23 \%$ & $7.97 \%$ & $3.16 \%$ \\
\hline Elections in Andalusia (March 2015) & $26.76 \%$ & $35.43 \%$ & $14.84 \%$ & $9.28 \%$ \\
\hline Regional elections - Madrid & $33.1 \%$ & $25.44 \%$ & $18.59 \%$ & $12.14 \%$ \\
\hline Regional elections - Valencia & $26.25 \%$ & $20.3 \%$ & $11.23 \%$ & $12.31 \%$ \\
\hline Local elections - Madrid & $34.55 \%$ & $15.28 \%$ & $31.85 \%$ & $11.41 \%$ \\
\hline Local elections - Barcelona & $8.7 \%$ & $9.63 \%$ & $25.21 \%$ & $11.05 \%$ \\
\hline Local elections - Valencia & $25.71 \%$ & $14.07 \%$ & $9.81 \%$ & $15.38 \%$ \\
\hline Local elections - Seville & $33.08 \%$ & $32.14 \%$ & $9.01 \%$ & $9.03 \%$ \\
\hline Local elections - Zaragoza & $26.88 \%$ & $18.65 \%$ & $24.57 \%$ & $12.29 \%$ \\
\hline Elections in Catalonia (September 2015) & $8.5 \%$ & $12.74 \%$ & $8.94 \%$ & $17.93 \%$ \\
\hline National elections (December 2015) & $28.7 \%$ & $22 \%$ & $20.7 \%$ & $13.9 \%$ \\
\hline National elections (June 2016) & $33.03 \%$ & $22.66 \%$ & $21 \%$ & $13.05 \%$ \\
\hline
\end{tabular}

Source: author

The following table displays a summary of the votes cast for the four major parties in the different electoral contests having taken place in Spain since May 2014. Included are the results of the European Elections, the elections of the four most populous regions of Spain where elections were held, and those of the five biggest cities. Finally, we can see the results of December 2015 and June 2016 national elections. ${ }^{4}$ To this end, we should point out that in Barcelona and Valencia, in order to obtain a detailed image of the electoral map, the nationalist and local parties should also be included - some had excellent results, with $\mathrm{CiU}$ as the second most voted for party in Barcelona and Compromís the second most voted for in Valencia. Furthermore, in local elections, the candidacy did not exclusively pertain to Podemos, but

4 Podemos ran for this election co-allied with Izquierda Unida, which obtained $3.67 \%$ of popular vote in 2015 elections. rather came from a popular unity in which Podemos participated. In fact, Podemos did not run for municipal office under that name, and in the country's most populous cities it only participated in popular unity candidacies.

Still to be analysed is the demographic make-up of the Podemos electorate. To that end, the work of Fernández-Albertos, featuring an analysis of the 2014 European elections results and the information provided by subsequent CIS polls (Spain's institute of public opinion surveys) proves quite illustrative. The data therein reveal a wide pool from which Podemos draws its votes, mostly from IU and PSOE, with a smaller but hardly insignificant percentage coming from the PP and from abstainers (Fernández-Albertos, 2015: 86).

Regarding demographics for Podemos voters in the 2014 European elections, the average voter is more urban than rural. The party's voters are concen- 
trated in Madrid, where most of its leaders hail from, but there is also a marked uniformity throughout all of Spain, including highly competitive, difficult regions such as Catalonia. The economic crisis proves to be a determining factor in a voter's support of the party or lack thereof, especially in the strongholds of the left (Fernández Albertos, 2015: 78). Lastly, the post-electoral CIS data show the decisive weight of the youth vote for Podemos and the generation gap that arises beginning in May 2014 between voters of the new parties, especially Podemos, who are mostly young, and those of the PP and PSOE, most of whom are over 50 .

According to Fernández-Albertos' hypothesis, the Podemos voter profile changes after the 2014 European elections. Leading up to the elections, the average Podemos voter was young, highly politicized, up-to-date on current events, and an avid user of the Internet and social networks as a tool for getting informed and interacting socially (Fernández-Albertos, 2015: 50). An activist profile, generally urban, which would, as per subsequent CIS polls, later become more transversal and also harder hit by the crisis.

Such a shift, indeed, seems logical: the party's initial supporters are the political equivalent of early adopters, those who knew of the party from its onset and decided to vote for its candidates in an electoral contest which, lest we forget, has low voter participation rates - just $45.84 \%$ in 2014 . Later on, the party's existence having been solidified due to its electoral results and its constant presence in the media, the larger public becomes aware of Podemos. From this group as a whole the party would earn the votes of those citizens most dissatisfied with Spain's situation, mainly due to the economic crisis and the direct effect that it has had on most people's lives. Thus, in the words of Fernández-Albertos, having begun as the "party of the indignados", Podemos would become "the party of the excluded".

\section{Conclusions}

Our analysis of the characteristics and evolution of Podemos, both as a party and as a political phenomenon, has sought to offer a wide and varied perspective that deals with the internal as well as external factors of this political force. We have deduced, from outside information such as polls, electoral results and TV audience ratings, and from internal decisions such as a turn towards the political centre, a moderation of the party's discourse and an increasingly hierarchized structure, that Podemos has traversed an initial effervescent phase. During this phase, the party's populist rhetoric saw not only electoral success, but also the public's fascination and the integration within the party's internal dynamics of direct democracy logic. Now, Podemos has reached a period of stabilization. The party may find itself in a transition phase between the insurgent phase and the established phase, in keeping with the four phases of populist parties (Mazzoleni, 2014: 51-52).

During this transition, Podemos's "winning formula" seems to have run its course. In the tension which has existed from the party's onset between the decentralization of the assemblies and the hyper-leadership in the media, the latter is much more likely to prevail. The way Podemos calls upon its sympathizers to take action, albeit constant, has slowly but surely proven to be more of an instrumental resource than as an effective means of participation. The data show a 
decline in the party's standing in comparison with its electoral apex, but also a recovery in the most recent 2015 and 2016 electoral processes, where Podemos has been the third political party, close to the second one (PSOE).

Politics today, in the case of the Spanish parties that have sprung up over the last year as an alternative to the according to many - dilapidated traditional two-party system, still revolves much more around television than social networks and the Internet. Nonetheless, in keeping with Chadwick (2013), we must not underestimate the importance of the latter as an alternative and complement to television.

\section{REFERENCES}

Bimber, Bruce (1998) The Internet and Political Transformation: Populism, Community, and Accelerated Pluralism. Polity 31(1): 133-160. DOI: 10.2307/ 3235370

Boix Palop, Andrés and López García, Guilermo (2014) El significado de las Elecciones Europeas de 2014 en España: giro a la izquierda y hundimiento del bipartidismo (The meaning of the 2014 European Elections in Spain: shift to the left and sinking of bipartisanship). Revista Aranzadi Unión Europea 7: 69-93.

Chadwick, Andrew (2013) The hybrid media system: politics and power. New York: Oxford University Press. DOI: 10.1093/acprof:oso/9780199759477. 001.0001

Casero-Ripollés, Andreu and Feenstra, Ramón A. (2012) The 15-M Movement and the new media: A case study of how new themes were introduced into
In fact, the very phenomenon of political debate programs, motivated by public disaffection for conventional political parties and forums, combined with political interest and involvement, is related to the emergence of a new type of "electrifying" political leaders, of whom Pablo Iglesias is the main, though not the only example. With the exception of Prime Minister Mariano Rajoy, the leaders of the major parties (Albert Rivera of Ciudadanos, Pedro Sánchez of PSOE, Alberto Garzón of IU and Iglesias himself) have turned their television appearances and TV personality into one of their primary sources of political capital.

Spanish political discourse. MIA: Media International Australia 144: 68-76. DOI: $10.1177 / 1329878 X 1214400111$

Casero-Ripollés, Andreu, Feenstra, Ramón A. and Tormey, Simon (2016) Old and New Media Logics in an Electoral Campaign: the Case of Podemos and the Two-Way Street Mediatization of Politics. The International Journal of Press/Politics 21(3): 378-397. DOI: $10.1177 / 1940161216645340$

Domínguez, Ana et al. (2014) Claro que Podemos. De La Tuerka a la esperanza del cambio en España (Of course we can. From 'La Tuerka' to the hope of change in Spain). Barcelona: Los Libros del Lince.

Elmundo.es (2015) http://www.elmundo.es/television/2015/02/24/54ec4c74268e3ee0108b4576.html Acceseed August 12th 2016

En.wikipedia.org (2015) https://en.wikipedia.org/wiki/Opinion_polling_for_ 
the_Spanish_general_election,_2015 Acceseed August 12th 2016

Errejón, Íñigo (2015) We the People. El 15-M: ¿un populismo indignado? ACME: An International E-Journal for Critical Geographies 14(1): 124-156.

Fenoll, Vicente and Sánchez-Castillo, Sebastián (2016) Discurso y participación política en Plaza Podemos. RAE-IC. Revista de la Asociación Española de Investigación de la Comunicación 3(5): 24-33.

Fernández-Albertos, Jose (2015) Los votantes de Podemos. Del partido de los indignados al partido de los excluidos (Podemos' voters. From the party of the outraged to the party of the excluded). Madrid: Libros de la Catarata.

Formulatv.com (2014) http://www.formulatv.com/noticias/41314/pablo-iglesias-evole-salimos-tv-privadas-rentables-audiencias-libertad/ Acceseed August 12th 2016

Giansante, Gianluca (2015) La comunicación política online (Online political communication). Barcelona: Editorial UOC.

Globalinmedia.com (2016) http://www. globalinmedia.com/impactosocial-pabloiglesias-24horas/ Acceseed August $12^{\text {th }} 2016$

Kesse, Stijn van (2014) The populist catdog: applying the concept of populism to contemporary European party systems. Journal of Political Ideologies 19(1): 99-118. DOI: $10.1080 / 13569317$. 2013.869457

Laclau, Ernesto (2005) La razón populista (On populist reason). Madrid: Fondo de Cultura Económica de España.
López García, Gillermo et al. (2015) El debate sobre Europa en Twitter. Discursos y estrategias de los candidatos de las elecciones al Parlamento Europeo de 2014 en España (The Debate about Europe on Twitter. Speeches and Strategies of the Candidates for the European Parlament Elections in 2014 in Spain). Revista de Estudios Políticos 170: 213-246.

Mazzoleni, Gianpietro (2014) Mediatization and Political Populism. In: Esser, Frank and Strömbäck, Jesper (eds) Mediatization of Politics: Understanding the Transformation of Western Democracies (pp. 42-56). New York: Palgrave Macmillan. DOI: 10.1057/9781 137275844

Micó, Josep-Lluís and Casero-Ripollés, Andreu (2013) Political activism online: organization and media relations in the case of $15 \mathrm{M}$ in Spain. Information, Communication \& Society 17(7): $858-871$. DOI: $10.1080 / 1369118 X$. 2013.830634

Periodismo.umh.es (2014) http://periodismo.umh.es/2014/11/10/periodismoumh-acoge-el-seminario-comunicarpodemos-politica-medios-y-ciudadania/ Acceseed August 12th 2016

Rivero, Jacobo (2015) Podemos. Objetivo: asaltar los cielos (Podemos. Objective: assault the heavens). Barcelona: Planeta.

Taguieff, Pierre-André (2002) L'illusion populiste (The populist illusion). Paris: Éditions Berg International. 


\section{Španjolsko “yes, we can!” protiv dvostranačkog sustava: razvoj političke stranke Podemos}

SAŽETAK Članak analizira unutarnje funkcioniranje španjolske političke stranke Podemos i njezine strukture. Uporabljena metodologija sastoji se od: 1) deskriptivne analize razvoja Podemosa, utemeljene na podacima dostupnima iz medija; 2) analize usmjerene na prisutnost Podemosa na društvenim mrežama i mainstream medijima, uz izborne rezultate i ankete. Analiza nastoji odrediti sljedeće: kakav je proces odlučivanja u stranci te kakvi su odnosi uspostavljeni između vođa i pristaša; u kojoj je mjeri uporaba interneta primarni alat za organizaciju, mobilizaciju i političku propagandu; te razinu (ne)sklada unutarstranačke dinamike djelovanja između s jedne strane, "odozdo prema gore" strukture građanskih vijeća i, s druge, "odozgo prema dolje" strukture hipervodstva Pabla Iglesiasa i medijske prisutnosti glavnih vođa stranke.

KLJUČNE RIJEČI Podemos, europski izbori, novi mediji, španjolska politika, politički populizam 